DOI 10.26886/2520-7474.2(40)2020.6

UDC: $[94(470+571): 614.885]$ «1914/1918»

\title{
SOCIETY OF RED CROSS IN AN INITIAL PERIOD OF FIRST WORLD WAR (1914-1915): MOBILIZATION AND FORMATION OF NEW STRUTURES
}

\section{W. Orehowsky, Doctor of Historical Sciences}

Chernivtsi trade and economic institute of the Kyiv national trade and economic university, Ukraine, Chernivtsi

filos@chtei-knteu.cv.ua

In the article the problems of preparation of Russian society of Red Cross are illuminated on the grant of help to the wounded and sick patients military in the years of First World War. Considerable attention an author concentrates on a process to mobilization of establishments and medical staff of Society. Marked at the same time, that the necessities of war-time considerably extended the circle of duties of Red Cross as in a quantitative plan so after directions of activity. An author marks that Russian Red Cross became one of the most considerable helpers of military administration on business help to help to the wounded and sick.

Keywords: First World War, Russian society of Red Cross, public health organizations, medicine, charity, help to the wounded and sick

доктор історичних наук, Ореховський В. О. Товариство Червоного Хреста у початковий період Першої світової війни (19141915 рр.): мобілізація та формування нових структур / Чернівецький торговельно-економічний інститут Київського національного торговельно-економічного університету, Україна, Чернівці

У статті висвітлюються проблеми підготовки Російського товариства Червоного Хреста по наданню допомоги пораненим та хворим військовим у роки Першої світової війни. Значну увагу автор 
зосереджує на процесі мобілізації закладів та медперсоналу Товариства. В той же час відзначається, що потреби військового часу значно розширили коло обов'язків Червоного Хреста як у кількісному плані так і за напрямами діяльності. Автор наголошує, що Російський Червоний Хрест став одним з найбільш значних помічників військової адміністрації у справі допомоги пораненим та хворим.

Ключові слова: Перша світова війна, Російське товариство Червоного Хреста, громадські військово-санітарні організації, медицина, благодійність, допомога пораненим та хворим.

доктор исторических наук, Ореховский В.О. Общество Красного Креста в начальный период Первой мировой войны (19141915 ге.): мобилизация и формирование новых структур / Черновицкий торгово-экономический институт Киевского национального торгово-экономического университета, Украина, Черновцы

В статье освещаются проблемы подготовки Российского общества Красного Креста по оказанию помощи раненым и больным военнослужащим в годы Первой мировой войны. Значительное внимание автор сосредоточивает на процессе мобилизации заведений и медперсонала Общества. В то же время отмечается, что потребности военного времени значительно расширили круг обязанностей Красного Креста как в количественном плане, так и по направлениям деятельности. Автор отмечает, что Российский Красный Крест стал одним из наиболее значительных помощников военной администрации в деле оказания помощи раненым и больным.

Ключевые слова: Первая мировая война, Российское общество Красного Креста, общественные военно-санитарные организации, медицина, благотворительность, помощь раненым и больным. 
Вступ. Перша світова війна (1914-11918 рр.) являється однією із сторінок військової історії, що була, є і буде предметом цікавості як професійних істориків так і любителів. Наслідками цього збройного конфлікту стали мільйони загиблих, поранених та скалічених; руйнація європейського господарства; революції та утворення нових держав.

Тема «Великої війни» ніколи не втрачала своєї актуальності. Однак, серед багатьох її аспектів $€$ один, що не знайшов адекватного відображення у вчених-істориків. Цим аспектом стала організація медичної допомоги на фронтах та у тилу діючої армії. I тут, одну з ключових ролей відіграло Російське Товариство Червоного Хреста (РТЧХ) - громадська організація, що передбачала надання допомоги пораненим, хворим та калікам. Саме його діяльність надала значної допомоги державній військовій медицині.

Аналіз останніх досліджень. Значущість подій 1914-1918 рр. привертали, привертають і будуть привертати до себе увагу істориків. Однак, незважаючи на широкий спектр документів, що висвічують політичну, військову, економічну складові цієї кампанії, історіографрія ряду проблем «Великої війни» $є$ досить обмеженою. Однією із таких «білих плям» $€$ проблема діяльності громадських благодійних організацій імперії.

Значне місце у науковому доробку, присвяченому діяльності медико-санітарних громадських організацій, в ому числі і Російського Червоного Хреста, посідають дисертаційні дослідження С.П.Кармалюка [1], О.В.Чистякова [2] та В.О.Соколової [3].

Свідченням зростанню інтересу до згаданої проблеми став ряд статей, що з'явилися у науковій періодиці. 3 подібних досліджень варто відмітити роботи А.Р. Борошенко [4], Л.є. Горєлової, Н.А. Рудой [5], 
О.М. Доніка [6], А.П.Єрошенко, А.П., Черкасова [7], К.О. Пахалюка [8] та iH.

Таким чином, за останні роки спостерігається кількісне зростання робіт, що присвячені вивченю історії діяльності РТЧХ. Однак, незважаючи на появу цілого ряду наукових досліджень, що так чи інакше зачіпають тему діяльності Російського Червоного Хреста, багато іï питань продовжує залишатися поза увагою вчених. Тому, наукова розробка даного питання продовжує залишатися одним 3 важливих завдань історичної науки. Це і визначило актуальність теми, обраної автором статті.

Метою даної публікації стало розкриття та характеристика заходів Товариства по мобілізації закладів та персоналу Червоного Хреста у початковий період Першої світової війни.

Виклад основного матеріалу. На початку XX ст. міжнародні відносини загострюються з новою силою. Багато країн включилися в гонку озброєнь. Було ясно, що світ невтримно котиться до безодні «великої», «загальної» війни, і правлячі кола усіх держав, відповідним чином, реагували на це.

Готувалась до війни і Російська імперія. За 1898-1913 рр. згідно звітам Державного контролю на фрлот і армію країна витратила більше 22\% всіх своїх бюджетних надходжень. Тільки за період між 1909 та 1913 рр. військове відомство отримало 4 млрд. крб. ( 3 млрд. - на розвиток сухопутної армії, 1 млрд. - на будівництво фрлоту)[9, с.321].

Новим кроком у розвитку збройних сил стало прийняття «Великої програми» (1913р.), що передбачала ряд заходів організаційного характеру, які скеровувались на збільшення чисельного складу армії (до майже 1,7 млн. солдатів та офріцерів) та упорядкування її устрою в усіх відношеннях [10, с.57-58]. 
Медико-санітарні потреби діючої армії мали забезпечувати чисельні медичні заклади. Допомога пораненим та хворим військовим покладалась на 143 рухомі (мобільні), 334 запасні та 53 кріпосні госпіталі (не враховуючи госпіталі, що були надані безпосередньо військам: по 2 на піхотну дивізію і по 1 на стрілецьку бригаду). При цьому до повного укомплектування не вистачало близько $10 \%$ мобільних медичних закладів, в той же час кількість запасних понад 5\% перевищували норму [11, с.295-296].

Перевезення поранених повинні були здійснювати 27 санітарних та 100 армійських транспорти, а необхідні медикаменти та перев'язувальні засоби планувалось отримувати з 7 польових аптек ( 2 - у Двінську та по одній - у Бобруйську, Москві, Києві, Петербурзі та Кременчуці) [11, с.296].

Передвоєнна підготовка не обійшла стороною і Товариства Червоного Хреста. У пояснювальній записці до «Керівництва по мобілізації закладів товариства Червоного Хреста військового часу» затвердженого Головним Управлінням (ГУ) РТЧХ у 1912 р. зазначалось: «Досвід минулих воєн, в яких брало участь Товариство Червоного Хреста, вказує, що його сприяння військовій адміністрації у справі допомоги пораненим та хворим воїнам виражалося, головним чином, в утриманні їх у власне Червоного Хреста лікарських закладах, більшою частиною сформованих спеціально для потреб військового часу.

Формування лікарських закладів Червоного Хреста військового часу розпочиналося, зазвичай, із проголошенням війни і, не будучи достатньо підготовленим у мирний час, зустрічало немало труднощів як у забезпеченні необхідним персоналом закладів, що формуються, так і належним обладнанням. 
Для успішного та швидкого формування із проголошенням мобілізації закладів Червоного Хреста військового часу в мирний час необхідно розробити всі міркування фрормування, на основі яких мають бути складені мобілізаційні плани, окремо на кожен заклад військового часу» $[12$, c.3].

Розробка цих планів покладалась на спеціальні мобілізаційні комісії. Останні обиралися терміном на три роки відповідними управліннями і комітетами у складі не менше трьох осіб із числа членів Російського товариства Червоного Хреста $[12$, с.6].

Після отримання від ГУ Товариства мобілізаційного наряду ( у ньому вказувалась необхідна кількість, тип закладів, що мали бути сформовані та чисельність їх персоналу) мобілізаційна комісія повинна була скласти поіменний список осіб (лікарів, медичних сестер), необхідних для укомплектування закладів Червоного Хреста військового часу. І з проголошення мобілізації комісія «...негайно сповіщає про те поіменно осіб, призначених для укомплектування закладів, що фрормуються,... і запрошує їх прибути на місце формування у вказаний термін» [12, с.8-9].

Для медичного закладу, що мав за планом розпочати свою діяльність, необхідно було ще у мирний час знайти придатні приміщення. Причому, «у мирний час мають бути з'ясовані та укладені, за можливості, писемні умови по наданню у користування намічених приміщень із проголошенням мобілізації» [12, с.10].

Всього, за Мобілізаційним планом, Товариство мало сформувати наступні заклади: 48 госпіталів на 200 ліжок; 33 рухомих лазарети; 10 передових загонів. Крім того, передбачалося створити резерви персоналу і мати достатні засоби для розгортання зазначених закладів на подвійне число ліжок, так щоб 13100 ліжок могли бути розгорнуті в 
26000. Виконання всіх цих заходів планувалося в 30-денний строк (у 3 черги) [13, с.83].

Для їх обслуговування Російському товариству Червоного Хреста «належало відрядити при мобілізації у військово-лікарські заклади, санітарні потяги та евакуаційні комісії 2826 сестер милосердя для закладів, мобілізованих у Європейській Росії, а із збільшенням закладів, мобілізованих у Туркестані, Сибіру і на Кавказі, - всього 4013 сестер милосердя» [13, с.81].

Крім особового складу заклади Червоного Хреста повинні були бути забезпечені також і необхідним майном «...згідно каталогів спорядження, затверджених Головним Управлінням» [12, с.11]. Цю місію мали виконувати центральний та фронтові склади РТЧХ, про які зазначалось, що у разі війни з них також бажано «мати можливість ... отримувати для поранених білизну і теплі речі, каву, какао, консерви, молоко, чай, цукор, вино, галети пшеничні та тютюн» [14, с.1755]. Пройшло зовсім небагато часу і цим планам судилось втілитись у життя.

15 (28) червня 1914 року пролунали постріли на Латинському мості боснійського міста Сараєво. Було вбито спадкоємця австро-угорського престолу принца Франца-Фердінанда, що стало зручним приводом для німецьких військово-промислових кіл розв'язати війну. Всі спроби залагодити конфлікт мирним шляхом зазнали невдачі. 15 (28) липня Австро-Угорщина, під тиском Німеччини, оголосила Сербії війну і в той же день її війська обстріляли Белград.

Стало ясно, що війни уникнути не вдасться. Російський імператор Микола II підписав наказ про загальну мобілізацію. Використавши це як привід, Німеччина 19 липня (1 серпня) 1914 р. оголосила Росії війну, а через два дні - Франції та Бельгії. 22 липня ( 4 серпня) до числа воюючих країн вступила і Англія. Розпочалась війна, яка за своїми 
масштабами і наслідками не мала собі рівних у всій попередній історії людства.

За кілька днів до цих подій, 14 (27) липня 1914 року відбулося термінове засідання ГУ РТЧХ. Воно було скликане «...для обговорення попередніх заходів для своєчасного і раціонального здійснення плану допомоги Червоного Хреста, і тих заходів, до яких необхідно буде вдатися при оголошенні мобілізації з огляду на те, що події останнього часу показали, що у найближчому майбутньому може знадобитися виступ Червоного Хреста у справі надання допомоги хворим і пораненим воїнам на театрі військових дій» [15, арк.19].

Для обслуговування військ Київського, Одеського, Московського і частини Казанського військових округів, які намічалося мобілізувати у першу чергу, Товариство Червоного Хреста за домовленістю 3 Головним військово-санітарним інспектором О.Я.Євдокимовим повинно було виставити 10 госпіталів на 200 ліжок і 18 етапних лазаретів на 50 ліжок кожний, Для забезпечення цих закладів всім необхідним Головний Склад Червоного Хреста (С.-Петербург) повинен був розпочати негайну відправку до Московського та Київського складів майна, необхідного для сформування вищевказаних лікарськосанітарних закладів. Крім того, планувалося довести майно усіх намічених до фрормування закладів другої і третьої черги до готовності першої черги із запасів Головного складу [15, арк.19зв.-20].

Несподівано постало питання про те, хто буде керувати діяльністю РТЧХ: Виконавча Комісія (як під час російсько-японської війни) чи ГУ. Після обговорення зійшлися на тому, що функцію керування на себе приймає ГУ, поповнене в міру необхідності «представниками громадських установ і знаючим особами». Останнє було негайно виконано після офіційного оголошення війни [16, арк.243]. 
Потреби військового часу викликали фрормування нових структур при ГУ РТЧХ. Було створено 7 нових відділів: 1) відділ контролю 3 Радою контролю на чолі; 2) відділ заготівель і складів на чолі з Радою складів; 3) відділ по пересуванню персоналу та вантажів Червоного Хреста; 4) відділ по кружечному та церковному зборах; 5) відділ по видачі довідок про вбитих та поранених воїнів; 6) довідкове Бюро про військовополонених та 7) бюро преси [17, с.617].

На початку війни Росія розгорнула два діючі фрронти та дві окремі діючі армії:

- Північно-Західний фрронт - проти Німеччини;

- Південно-Західний фронт - проти Австро-Угорщини;

- Окрема армія № 6 (Петроградська) - для охорони узбережжя Балтійського моря;

- Окрема армія № 7 (Одеська) - для охорони узбережжя Чорного моря.

Із проголошення Росії війни з боку Туреччини (жовтень 1914 р.) була сфрормована Окрема Кавказька армія, яка розгорнулася у 1917 р в Кавказький фронт [18, с.68-69].

Для керівництва роботою закладів Товариства в районі бойових дій на кожний фронт відряджалися головноуповноважені Червоного Хреста. У затвердженому ГУ РТЧХ «Наказі головноуповноваженим РТЧХ у районі армій фронту» говорилось, що головноуповноважений «...є, кожний у своєму районі, розпорядником усіх засобів приватної допомоги - особових, речових та грошових, що надходять як від закладів названого Товариства, так і від усіх інших організацій та окремих осіб» [19, арк.1].

На головноуповноважених Червоного Хреста покладалися такі обов'язки; а) загальне керівництво діяльністю установ Червоного Хреста і приватної допомоги взагалі; б) забезпечення медичних 
закладів військового і морського відомств сестрами милосердя та іншою санітарною обслугою; в) забезпечення цих закладів перев'язочними засобами, медикаментами, білизною, одягом, теплими речами, а також продуктами харчування, які не входять до табелю військового відомства; г) сприяння евакуації хворих та поранених, забезпечення їх білизною та одягом, а також забезпечення санітарних поїздів, пароплавів та збірних пунктів сестрами милосердя і санітарною обслугою; д) облаштування та утримання, в міру можливостей, евакуаційних потягів та санітарних транспортів [19, арк. 1-13в.]. Крім вищесказаного, головноуповноважений повинен був піклуватись «...про надання хворим допомоги моральної, докладаючи, між іншим, зусиль до полегшення їм листування 3 рідними і зносин 3 місцями їх батьківщини. Головноуповноважений, реагуючи на звернення до нього, у міру можливостей, збирає через уповноважених та інших підвідомчих йому осіб відомості про хворих, поранених, померлих та вбитих і передає їх на вимогу потребуючих» [19, арк. 1зв.].

У підпорядкуванні головноуповноважених були їх помічники і особовоуповноважені. Вони виконували окремі доручення головноуповноважених, а також завідували окремими галузями діяльності або закладами Червоного Хреста того чи іншого району [19, арк. 2].

У своїх розпорядженнях головноуповноважені підпорядковувались Головному начальнику постачання армії фронту [19, арк. 1].

Згідно вищезазначеній постанові весь театр військових дій був поділений на три райони: Північний, Північно-Західний, та ПівденноЗахідний. На чолі червонохресних закладів Північно-Західного району був поставлений член ГУ, генерал-майор почту Д.Я.Дашков; ПівденноЗахідного - член ГУ, сенатор Б.Є.Іваніцький і Північного району - 
генерал-лейтенант Є.М.Волков. При кожній окремій армії були призначені особовоуповноважені [16, арк. 247].

3 початком військових дій ГУ в особі свого голови О.О.Ільїна звернулося до імператора Миколи II з проханням прийняти РТЧХ під своє опікування, на час відсутності покровительки Товариства, імператриці Марії Федорівни, яка в цей час знаходилася за кордоном. Імператриця Олександра Федорівна взяла під свою опіку склади Червоного Хреста і об'єднала їх діяльність з роботою власних складів [16, 241 зв., 243 зв.].

Верховним начальником санітарної та евакуаційної частин було призначено принца О.П.Ольденбурзького, якому було доручено взяти на себе виконання справ, що ГУ РТЧХ прохало його виконати [15, арк.25зв.].

Розгортання закладів Російського Червоного Хреста проходило планомірно і організовано. Вже у серпні 1914 р. Товариством до діючої армії було надіслано 38 госпіталів, 30 етапних лазаретів, 20 рухомих лазаретів і 7 передових загонів [13, с.83]. Однак, безпрецедентні за розмахом і напругою військові дії та викликані цим колосальні втрати російської армії вимагали негайного збільшення кількості медичних закладів РТЧХ. Після виконання першочергового мобілізаційного плану ГУ РТЧХ негайно почало формувати додатково ще 12 госпіталів, 40 лазаретів та 16 передових загонів [16, арк.244].

Потреби війни викликали формування Червоним Хрестом закладів, що не передбачалися мобілізаційним планом: перев'язочнохарчових пунктів, санітарно-дезінфекційних загонів, автомобільних санітарних загонів, рентгенівських загонів та ін. До жовтня 1914 р. на фронтах діяло 55 спеціальних загонів, фрормування яких не передбачалось мобілізаційним планом [2, с.19]. 
Вже у серпні 1914 р. стала відчуватись нестача персоналу, в першу чергу сестер милосердя. В цих умовах ГУ Російського Червоного Хреста відкрило по всій країні спеціальні прискорені курси. Жінки, які закінчували їх, отримували кваліфікацію сестри милосердя військового часу. До лютого 1915 р. ці курси закінчили більше 11 тис. жінок. Однак і ця чисельність не могла задовольнити зростаючих потреб фронту. Тому у лютому 1916 р. спеціальним циркуляром ГУ РТЧХ дозволило общинам сестер милосердя розпочати додатковий набір на курси [2, с.20].

Для забезпечення господарських потреб Товариства ГУ відкрило у районі бойових дій 6 польових складів із запасом всього необхідного на 5 тис. ліжок у кожному і для передових позицій 17 окремих складів, 3 яких 8 були мобільними (на залізничних платформах) [7, с.61].

Разом з РТЧХ допомогу пораненим і хворим надавали й інші організації. Найбільшими з них були Всеросійський Земський Союз (В3С) і Всеросійський Союз Міст (ВСМ). Ці організації виникли 3 початком війни і повинні були відігравати роль помічників військовосанітарного відомства та РТЧХ. Вони були прийняті під прапор Червоного Хреста і користувалися всіма його правами, причому як В3С, так і ВСМ зберігали повну самостійність у вирішенні фрінансових питань, а також у справі організації власних закладів і внутрішнього розпорядку. Так як надання медичної допомоги на театрі військових дій взяли на себе військове відомство та РТЧХ, то на долю Земського і Міського Союзів випала справа організації евакуації та розміщення хворих і поранених офріцерів і солдат у внутрішніх губерніях імперії [20, c.6-8]. Вони були об'єднані під загальним керівництвом головноуповноваженого Червоного Хреста по Внутрішньому району О.Д.Самаріна [16, арк.244]. 
Таким чином, початок війни показав високу готовність Товариства. Мобілізаційний план практично повністю був виконаний за 8 тижнів

Однак, потреби військового часу викликали фрормування нових фрормувань, кількість яких весь час збільшувалася в міру зростання обсягу роботи Червоного Хреста.

3 самого початку бойових дій при штабах фронтів та армій почали діяти управління головноуповноважених і уповноважених РТЧХ, покликані сприяти військовій адміністрації у справі допомоги пораненим та хворим. У той самий час у тилу була розгорнута система територіальних органів, які взяли на себе відповідальність за збирання коштів, забезпечення і реабілітацію поранених військових.

\section{תimepamypa:}

1.Кармалюк С.П. (1998). Діяльність організацій Червоного Хреста в Україні в 1867 - 1920 рр.: Авторефр. дис. канд. іст. наук. Чернівці.

2. Чистяков О.В. (2009). Организационное устройство и деятельность Российского Общества Красного Креста в годы Первой мировой войны (1914-1918 ге.): автореф. дис. канд. истор. Наук. Москва.

3. Соколова В.А. (2014). Российское Общество Красного Креста (1867-1918 ге.); авторефр. дис. канд. истор. наук. СПб.

4. Борошенко А.P. (2016). Российское общество Красного Креста в годы Первой мировой войны. Успехи современной науки и образования, т.8, № 12, 195-197.

5. Горелова Л.Е., Рудой Н.А. (2013). Деятельность Российского Общества Красного Креста в Первой мировой войне. Проблемы социальной гигиены, здравоохранения и истории медицины, 6, 40-42. 
6. Донік О.М. (2005). Громадська благодійність в Україні в роки Першої світової війни. Проблеми історії України XIX - початку XX cm., 9. К., Інститут історії України НАН України. 61-86.

7. Ерошенко А.П., Черкасов А.А. (2010). Россия в Первой мировой войне (1914 - 1918 гг.): военно-санитарная деятельность Российского общества Красного Креста. История и историки в контексте времени, 7, 60-72.

8. Пахалюк К.А. (2016). Российское общество Красного Креста в годы Первой мировой войны (по воспоминаниям Э.П. Беннигсена). Om противостояния идеологий $к$ служению идеалам: российское общество в 1914-1945 г2. М.: Новый хронограф, 84-106.

9. Шацилло К.Ф. (1991). Последние военные программы Российской империи. Вопросы истории, 7, 224-233.

10. Ростунов И.И. (1976). Русский фрронт Первой мировой войны. М., Наука.

11. Зайончковский А.М. (1926). Подготовка России к Мировой войне. М., Государственное военное издательство.

12. Наставление для мобилизации учреждений Общества Красного Креста военного времени (1912). С.-Петербург: Государственная типография.

13. Санитарная служба русской армии в войне 1914-1917 ге. Сборник документов (1942). Куйбышев: Госвоениздат.

14. В.Е. (1915). О санитарном состоянии русской армии за 1912 год. Вестник Красного Креста, 5,1739-1758.

15. Центральний державний історичний архів України у Києві (далі ЦДІА України у Києві). - Ф.719. - Оп.1.- Спр. 2. 
16. ЦДІА України у Києві. - Ф.719. - Оп.1. - Спр.4.

17. Боцяновский В. (1916). Первые дни войны в Красном Кресте. Вестник Красного Креста, 2, 616-625.

18. Россия в войнах XX века: Cтатистическое исследование (2001). М., ОЛМА-ПРЕСС.

19. ЦДІА України у Києві. - Ф.719. - Оп.1- Спр.20.

20. Краткий очерк деятельности Всероссийского Земского Союза (1916). Москва.

\section{References:}

1. Karmaliuk S.P. (1998). Diialnist of orhanizatsii of Chervonoho Khresta $v$ of Ukraini of $v 1867$ - 1920 rr. [Activity of organizations of Red Cross is in Ukraine in 1867 - 1920]. Avtoref. dys. kand. ist. nauk. Chernivtsi. [in of Ukrainian].

2. Chistjakov O.V. (2009). Organizacionnoe ustrojstvo i dejatel'nost' Rossijskogo Obshhestva Krasnogo Kresta $v$ gody Pervoj mirovoj vojny (1914-1918 gg.). [Organizational structure and activities of the Russian Red Cross Society during the First World War (1914-1918)]. Avtoref. dis. kand. istor. Nauk. Moskva. [in Russian].

3. Sokolova V.A. (2014). Rossijskoe Obshhestvo Krasnogo Kresta (18671918 gg.) [Russian Society of Red Cross (1867-1918)]. Avtoref. dis. kand. istor. nauk. SPb. [in Russian].

4. Boroshenko A.R. (2016). Rossijskoe obshhestvo Krasnogo Kresta v gody Pervoj mirovoj vojny [Russian society of Red Cross in the years of First world war]. Uspehi sovremennoj nauki i obrazovanija [Successes of modern science and education], t.8, no. 12, 195-197. [in Russian].

5. Gorelova L.E., Rudoj N.A. (2013). Dejatel'nost' Rossijskogo Obshhestva Krasnogo Kresta v Pervoj mirovoj vojne [Activity of Russian Society of Red Cross is in First world war]. Problemy social'noj gigieny, zdravoohranenija $i$ 
istorii mediciny [Problems of social hygiene, health protection and history of medicine], no.6, 40-42. [in Russian].

6. Donik O.M. (2005). Hromadska of blahodiinist $v$ of Ukraini of $v$ roky of Pershoi of svitovoi viiny [Public charity is in Ukraine in the years of First World War]. Problemy of istorii of Ukrainy XIX - pochatku of XX of st.[ Problem of history of Ukraine XIX - beginning of XX of century], no.9. K.: Instytut of istorii of Ukrainy NAN Ukrainy. 61-86. [in of Ukrainian].

7. Eroshenko A.P., Cherkasov A.A. (2010). Rossija v Pervoj mirovoj vojne (1914 - 1918 gg.): voenno - sanitarnaja dejatel'nost' Rossijskogo obshhestva Krasnogo Kresta [Russia is in First world war (1914 - 1918): military health activity of Russian society of Red Cross]. Istorija $i$ istoriki v kontekste vremeni [History and historians are in the context of time], no. 7, 60-72. [in Russian].

8. Pahaljuk K.A. (2016). Rossijskoe obshhestvo Krasnogo Kresta v gody Pervoj mirovoj vojny (po vospominanijam Je.P. Bennigsena) [Russian society of Red Cross in the years of First world war (on remembrances of Je.P. Bennigsena)]. Ot protivostojanija ideologij $k$ sluzheniju idealam: rossijskoe obshhestvo $v$ 1914-1945 gg.[From opposition of ideologies to service to the ideals: Russian society in 1914-1945]. M., Novyj hronograf, 84-106. [in Russian].

9. Shacillo K.F. (1991). Poslednie voennye programmy Rossijskoj imperii [Last soldiery programs of the Russian empire]. Voprosy istorii [Questions of history], no.7, 224-233. [in Russian].

10. Rostunov I.I. (1976). Russkij front Pervoj mirovoj vojny [Russian front of First World War]. M., Nauka. [in Russian].

11. Zajonchkovskij A.M. (1926). Podgotovka Rossii k Mirovoj vojne [Preparation of Russia to World war]. M., Gosudarstvennoe voennoe izdatel'stvo. [in Russian]. 
12. Nastavlenie dlja mobilizacii uchrezhdenij Obshhestva Krasnogo Kresta voennogo vremeni [Discipling for mobilization of establishments of Society of Red Cross of war-time]. (1912). S.-Peterburg, Gosudarstvennaja tipografija. [in Russian].

13. Sanitarnaja sluzhba russkoj armii v vojne 1914-1917 gg. Sbornik dokumentov [Sanitary corps of the Russian army in war 1914-1917. Collection of documents]. (1942). Kujbyshev, Gosvoenizdat. [in Russian].

14. V.E. (1915). O sanitarnom sostojanii russkoj armii za 1912 god [About the sanitary state of the Russian army for 1912]. Vestnik Krasnogo Kresta [Announcer of Red Cross], 5,1739-1758. [in Russian].

15. Tsentralnyi of derzhavnyi istorychnyi arkhiv of Ukrainy u Kyievi [A central record historical office of Ukraine is in Kyiv] (dali - TsDIA Ukrainy u of Kyievi) [farther - CRHO of Ukraine in Kyiv]. - F.719. - Op.1.- Spr. 2. [in of Russian].

16. TsDIA Ukrainy u Kyievi [CRHO of Ukraine in Kyiv]. - F.719. - Op.1. Spr.4. [in Russian].

17. Bocjanovskij V. (1916). Pervye dni vojny v Krasnom Kreste [The first days of war are in Red Cross]. Vestnik Krasnogo Kresta [Announcer of Red Cross], 2, 616-625. [in Russian].

18. Rossija v vojnah $H H$ veka: Statisticheskoe issledovanie [Russia is in wars of XX of century: Statistical research]. (2001). M., OLMA - PRESS. [in Russian].

19. TsDIA Ukrainy u Kyievi [CRHO of Ukraine in Kyiv]. - F.719. - Op.1Spr.20. [in Russian].

20. Kratkij ocherk dejatel'nosti Vserossijskogo Zemskogo Sojuza [Short essay of activity of All-russian Zemsky Union] (1916). Moskva. [in Russian]. 